\title{
Familial mental retardation in a family with an inherited chromosome rearrangement
}

\author{
A. E. CHUDLEY, $\dagger$ F. BAUDER, $\ddagger$ M. RAY,** PHYLLIS J. MCALPINE,** \\ S. D. J. PENA, ${ }^{* *}$ and J. L. HAMERTON**
}

Summary. A family of three generations has been described with an insertional type of chromosome rearrangement involving chromosomes 11 and 18 [46,XX or $\mathrm{XY}$, ins $(11 ; 18)(\mathrm{p} 15 ; \mathrm{q} 11 \mathrm{q} 21)$ ] detected by G-banding using a trypsin digestion method. Four members of this family with clinical features of $18 \mathrm{q}-$ have inherited the $\operatorname{der}(18)$ from their father and are thus deficient for (18)(q11q21). Three other family members have inherited the $\operatorname{der}(11)$ and thus have a duplication of the same segment [(18)(q11q21)]. Genetic marker studies on this family, show no significant segregation of any of the markers studied with either the $\operatorname{der}(11)$ or $\operatorname{der}(18)$. Eight family members had the $P e p A^{8} P e p A^{1}$ genotype and four of these were carrying the der(18), indicating that the PepA locus which had been previously assigned to chromosome 18 , does not lie in the segment $q 11 \rightarrow \mathrm{q} 21$.

Since the initial report by de Grouchy et al (1964) over 50 cases of $18 q$ - have been described (Wertelecki and Gerald, 1971; Lurie and Lazjuk, 1972). Familial occurrences of $18 q-$ have also been observed usually resulting from the segregation of a balanced chromosome rearrangement in one of the parents (Law and Masterson, 1966; Valdmanis et al 1967; Jacobsen et al 1971; Rudd and LaMarche, 1971; Gouw, Ten Kate, and Anders, 1973).

Previous cytogenetic studies of $18 \mathrm{q}$ - individuals were unable to distinguish terminal from interstitial deletions. With the advent of Q- and Gbanding techniques (Caspersson, Zech, and Johansson, 1970; Seabright, 1971; Sumner, Evans, and Buckland, 1971 ; Wang and Federoff, 1972; Hamerton, Ray, and Douglas, 1973), specific areas of each chromosome can be readily identified (Paris Conference, 1971). We report here a family with an insertional type of chromosome rearrangement involving chromosomes 11 and 18 detected by Gbanding. The rearrangement was shown to be

\footnotetext{
Received 29 March 1974.

* Reprint requests to: Dr J. L. Hamerton, Department of Genetics, Health Sciences Children's Centre, 685 Bannatyne Avenue, Winnipeg, Manitoba, Canada.

t Faculty of Medicine, University of Manitoba.

$¥$ Health Sciences Children's Centre.

** Division of Genetics (Department of Pediatrics), University of Manitoba and Health Sciences Children's Centre, Winnipeg, Manitoba, Canada.
}

segregating through three generations and resulted in four subjects with an $18 \mathrm{q}$ - karyotype, of whom three were definitely mentally retarded and the fourth was too young for her mental status to be determined.

\section{Materials and methods}

Blood samples were collected from available family members and lymphocyte cultures established by standard methods. Air dried preparations were stained conventionally, using orcein, and for G-banding by the method described previously (Hamerton et al, 1973). White blood cells were analysed by the method of Lewis (1973) for their peptidase A (PepA) phenotypes. Red blood cells and plasma were analysed by standard procedures to determine the phenotypes of the other genetic markers listed in Appendix I (pp. 364-365). Quantitative levels of IgA, IgM, and IgG were determined by quantitative immunodiffusion. Dermatoglyphic analysis was carried out according to the methods of Holt (1968). The chromosome nomenclature used is that recommended by the Paris Conference (1971).

The pedigree of the family is given in Fig. 1 and the family data summarized in Appendix II (p. 366). Detailed clinical observations on certain family members are given below. Data on the other family members are given in Appendix II.

\section{Case Reports}

III.6. The propositus (Fig. 2) presented at the age of 
I
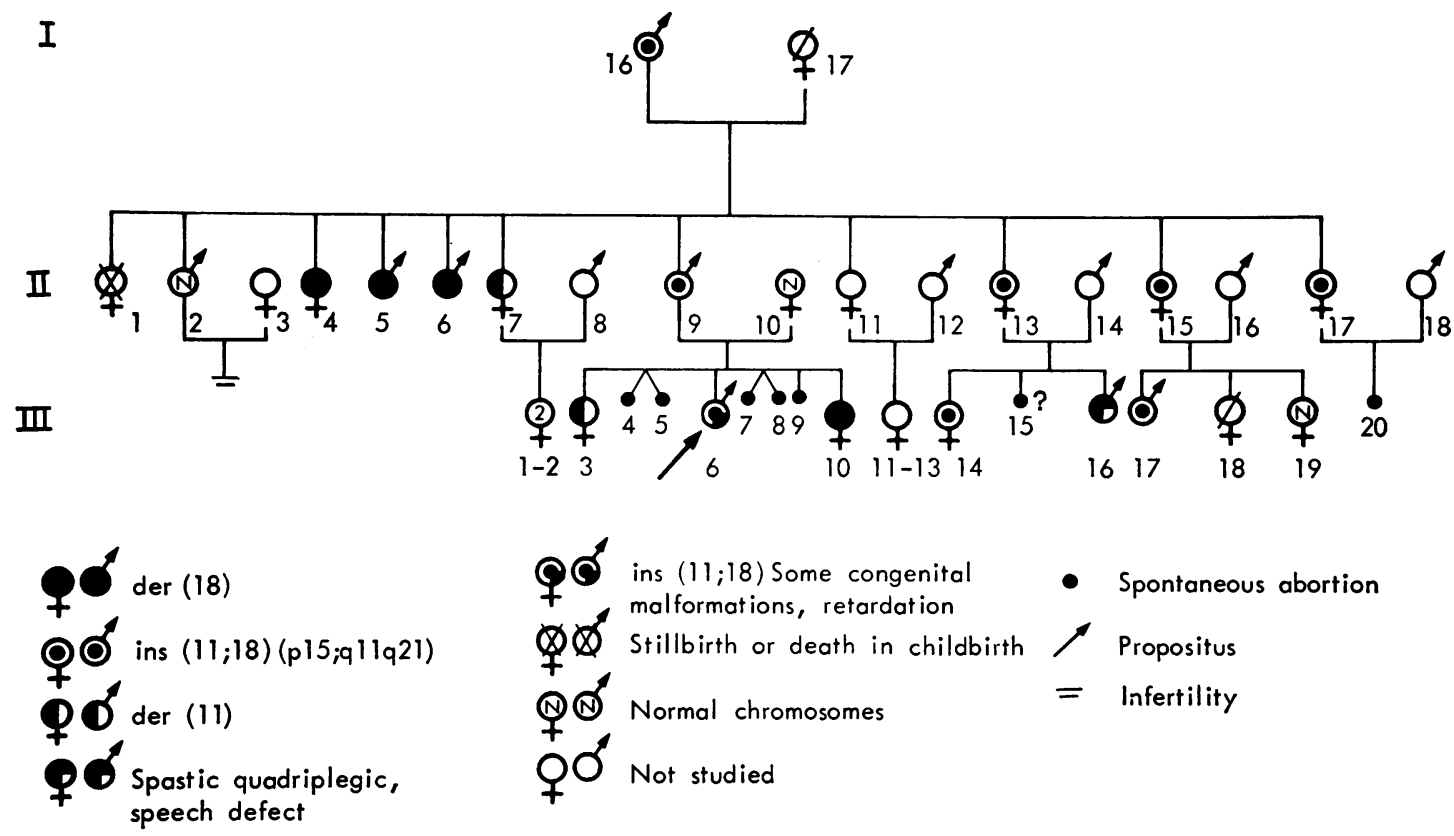

Fig. 1. Pedigree of the family.

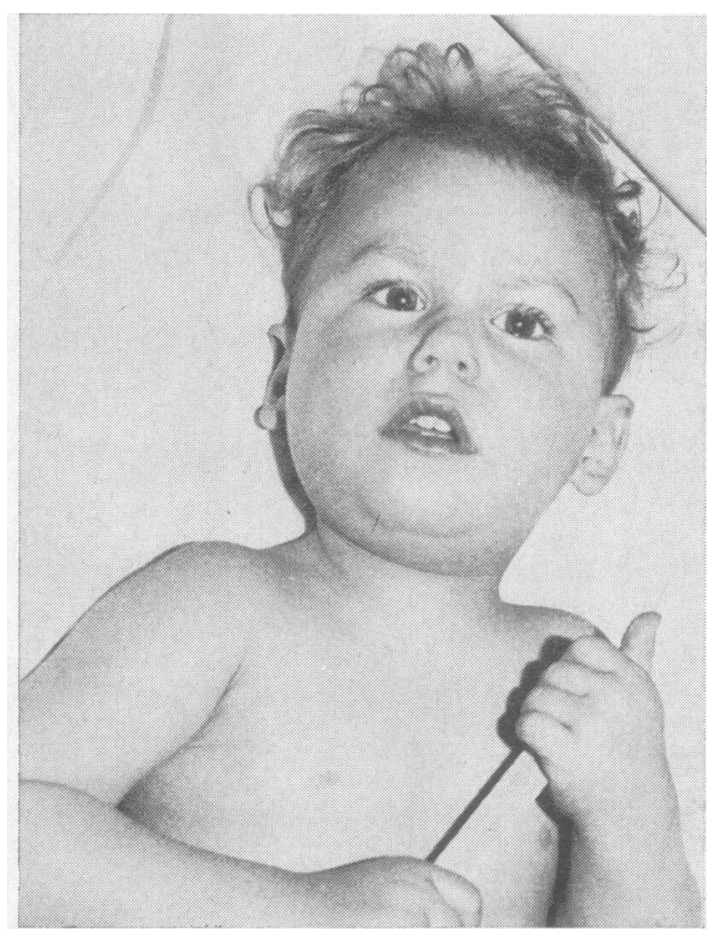

Fig. 2. Propositus (case III.6) at 28 months of age.
23 months for investigation of physical and mental retardation. He was the product of a full-term pregnancy, complicated by pre-eclampsia and antenatal haemorrhage; delivery was normal. The maternal age at his birth was 22 years. At birth his weight was $2825 \mathrm{~g}$ e ( $<10$ th centile), length $50.5 \mathrm{~cm}$ (50th centile), and head circumference $33.5 \mathrm{~cm}$ ( $<10$ th centile); it was noted that he had bilateral clubbed feet.

At 23 months, his developmental milestones were reported to be retarded; he had not yet begun to speak and had only begun to pull himself up to standing position. His parents described him as a cold and unaffectionate child. On physical examination, head circumference was $45.2 \mathrm{~cm}$, weight $10.2 \mathrm{~kg}$, and length $82 \mathrm{~cm}$, all of which were below the third centile. There was a periodic esophoria of the left eye; the fundi were normal. Neurological examination showed a mild degree of generalized hypotonicity associated with increased patellar tendon reflexes and extensor response on plantar stimulation. No other physical abnormalities were noted. Investigations done at this time showed a normal electroencephalogram, normal skull films and a negative complement fixation test for syphilis. Haematological and biochemical results were all within normal limits. Paper chromatography of amino acids in the urine revealed no abnormalities. At 23 months developmental performance was that of a 10-month-old child.

III.3 (Fig. 3). This subject was the $3300 \mathrm{~g}$ product of a full-term pregnancy which was complicated by preeclampsia; delivery was normal. To date, she has been healthy and has reached her expected developmental 


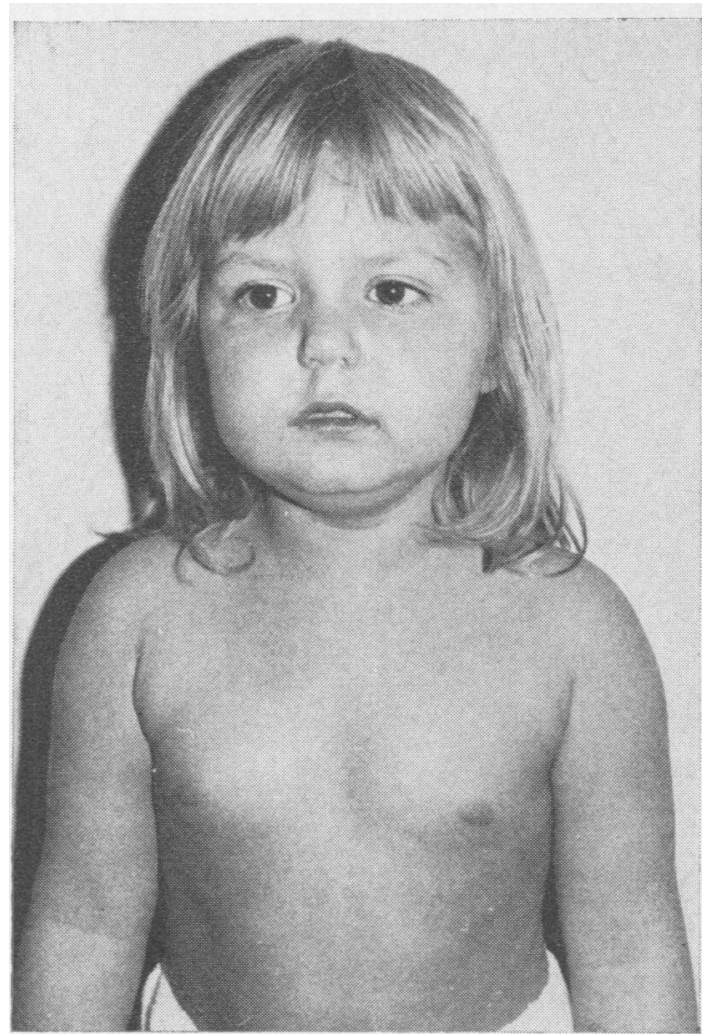

FIg. 3. Case III.3 at the age of 3 years 9 months. She is phenotypically normal.

milestones. On examination at 45 months, she was a healthy, active girl. Head circumference was $48 \mathrm{~cm}$ ( $<10$ th centile), weight $17.6 \mathrm{~kg}$ (75th centile), and height $96.5 \mathrm{~cm}$ (10th centile). Bilateral subacromial dimples were present. The remainder of the physical examination revealed no abnormalities.

III.10 (Fig. 4). This child was the product of a 40week pregnancy complicated by pre-eclampsia and a urinary tract infection. Artificial rupture of membrane was carried out and delivery was by mid-forceps rotation. At birth, she weighed $3473 \mathrm{~g}$ (50th centile), length was $54.6 \mathrm{~cm}$ ( $<97$ th centile), and head circumference $37.5 \mathrm{~cm}$ ( $<97$ th centile). The child has been healthy and seems to be developing normally.

On examination at 8 months, she was lively and active with a head circumference of $41.5 \mathrm{~cm}$ (< third centile), a length of $72 \mathrm{~cm}$ (97th centile), and a weight of $8.27 \mathrm{~kg}$ (50th centile). Her head had a flat occiput and was brachycephalic. She had a flattened nasal bridge, bilateral epicanthic folds, upward slanting palpebral fissures, prominent antihelices, slight mid-facial retraction, a carp-shaped mouth, and a high arched palate. The tip of the spleen was palpable $1 \mathrm{~cm}$ below the left costal margin. The remainder of the examination was normal.

II.4 (Fig. 5). This 42-year old paternal aunt of the propositus, was the third of 11 liveborn children, born at a maternal age of 22 years and a paternal age of 42 years. The mother died at the age of 63 from a postoperative pulmonary embolus. The father is suffering from Parkinson's disease. No details of the patient's birth could be obtained.

At the age of 9, the patient was admitted to the Manitoba School for the mentally retarded. At that time, a provisional diagnosis of 'cultural familial mental retardation' was made.

At the time of examination, the patient was severely retarded, spoke in an infantile manner, and showed ataxia. Her mental age was given as 2 years 8 months on the Stanford Binet intelligence scale. Height was 165 $\mathrm{cm}$, sole-to-pubis measurement $78.8 \mathrm{~cm}$, span $161 \mathrm{~cm}$, and head circumference $51.7 \mathrm{~cm}$. She weighed $65 \cdot 6 \mathrm{~kg}$. She had deep-set eyes, hypotelorism (interpupillary distance $58 \mathrm{~mm}$ ), and mild mid-facial retraction. There was no discernible squint. Fundoscopic examination revealed an absent red reflex with bilateral diffuse lenticular cataracts. Prominent antihelices were present. The patient had a carp-shaped mouth. The hearing was grossly normal. The patient was obese with a protruberant abdomen; the remainder of the physical examination was within normal limits.

II.5. No details of the pregnancy or birth history are available. There was a history of convulsions in childhood, which have since subsided. An EEG carried out in 1955 showed abnormal patterns in the posterior areas. During late childhood, the patient was admitted to the Manitoba School for the Mentally Retarded and was known to be aggressive and violent.

On physical examination at 40 years of age, he was ataxic and showed frequent bouts of head-rolling. Height was $169 \mathrm{~cm}$, sole-to-pubis distance $82 \mathrm{~cm}$, arm span $160.5 \mathrm{~cm}$, weight $66 \mathrm{~kg}$, and head circumference was $50.5 \mathrm{~cm}$. His occiput was noticeably flat and his face distorted by numerous scars. Slight hypotelorism was evident (interpupillary distance $58 \mathrm{~mm}$ ). An opaque cataract was obvious in the left eye while the right eye appeared normal on fundoscopic examination. The patient's pinnae exhibited prominent antihelices and large antitragi. The external auditory canals did not appear narrowed, and hearing was not grossly impaired. The palate was strikingly high-arched and narrow. The right testis was small. The metacarpophalangeal joints on both hands showed abnormalities resulting from multiple trauma, and he had bilateral pes planus. The patient gave no scorable responses, on numerous psychological tests that were attempted.

II.6. This subject was admitted to the Manitoba School for the mentally retarded during late childhood. On examination at the age of 38 he was moderately obese, fairly well co-ordinated, but showed almost constant head rolling. Height was $166.4 \mathrm{~cm}$, pubis-to-sole 


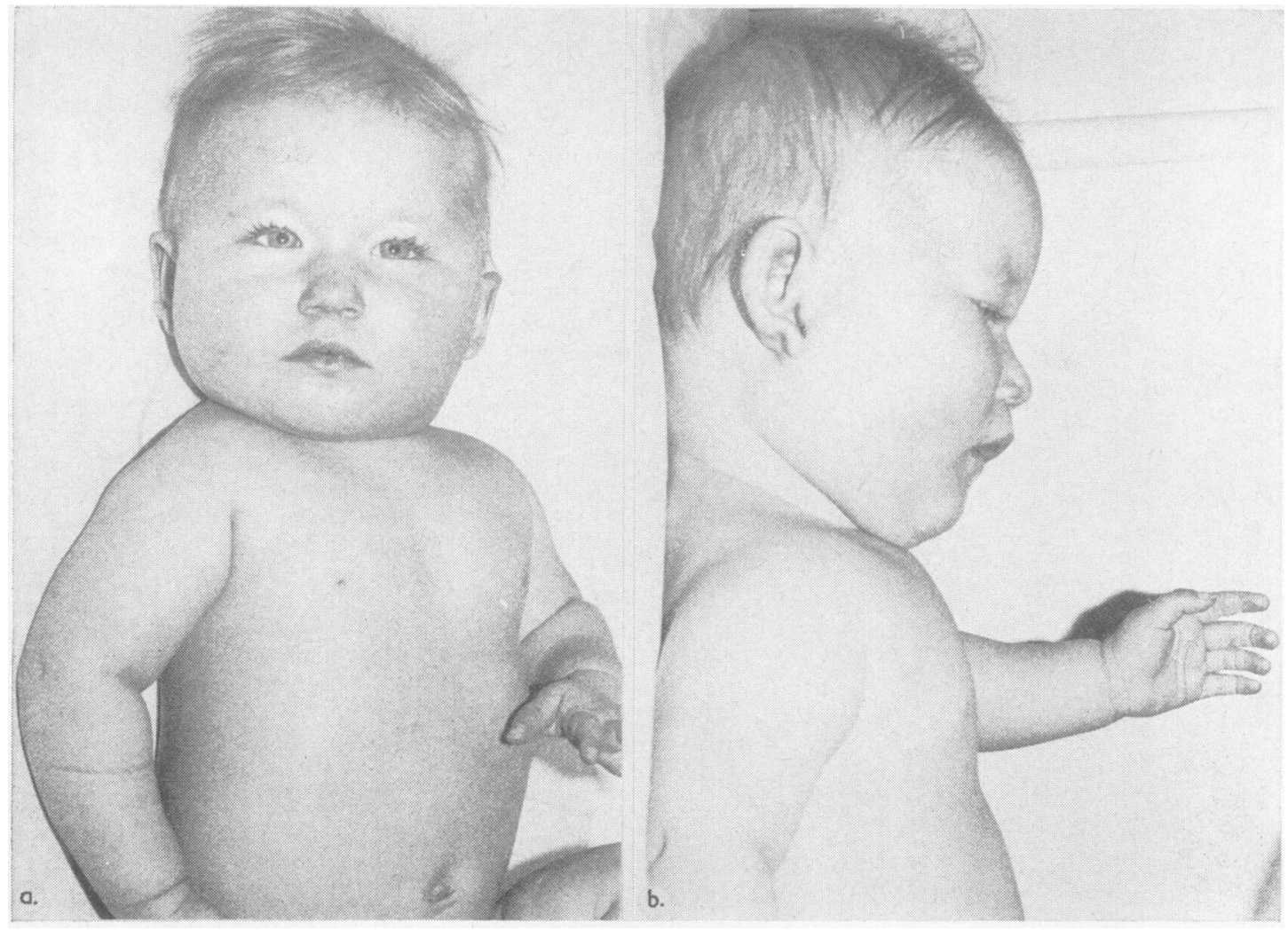

FIG. 4a. Case III.10 at 8 months of age showing bilateral epicanthic folds, mongoloid slant and carp-shaped mouth. FIG. 4b. Side view of case III.10 showing mild mid-facial retraction.

measurement $79 \mathrm{~cm}$, arm span $169 \mathrm{~cm}$, weight $74 \mathrm{~kg}$, and head circumference $57 \mathrm{~cm}$. The eyes were deep set and exhibited slight hypotelorism (interpupillary distance $57 \mathrm{~mm}$ ). A slight esophoria was present in the left eye. Both the retina and disc appeared normal on fundoscopic examination. Both ears showed prominent antitragi, and a prominent antihelix was evident on the right pinna. The abdomen was protruberant. No other physical abnormalities were detected. The patient had a recent psychological evaluation which showed a verbal IQ of 44 and a performance IQ of 40 .

\section{Chromosome analysis}

The propositus (III.6), his father (II.9), three of his aunts (II.13, II.15, and II.17), his grandfather (I.16), and two cousins (III.14 and III.17) were all shown to have a balanced insertional type chromosome rearrangement involving chromosomes 18 and 11 , in which the chromosome segment (18) (q11q21) had been inserted into band p15 of chromosome $11,[46, \mathrm{XX}$ or $\mathrm{XY}$,ins $(11 ; 18)(\mathrm{p} 15 ; \mathrm{q} 11 \mathrm{q} 21)]$ (Fig. 6$)$. Chromosome analysis of II.4, II.5, II.6, and III.10, showed that they had inherited the $\operatorname{der}(18)$ chro- mosome from their respective fathers, but otherwise had a normal karyotype $[46, \mathrm{XX}$ or XY, $-18,+$ der (18),ins $(11 ; 18)(p 15 ; q 11 q 21)$ pat]. Each of these individuals was thus deficient for the segment (18)(q11q21). Analysis of the chromosomes of II.7, III.3, and III.16, showed that they had each inherited the der(11) and had normal chromosomes 18 so that they each had a duplication of the (18) (q11q21) segment, [46,XX, $-11,+\operatorname{der}(11), \operatorname{ins}(11$; 18)(p15;q11q21)pat] (Fig. 7).

\section{Dermatoglyphics}

Dermatoglyphic data on those family members studied are given in Table I, together with some relevant population data. Parker et al (1972) has reported that the $18 \mathrm{q}$ - syndrome is characterized by complex digital patterns which can best be described as double or multiple loops $\left(\mathbb{W}^{\mathrm{d}}\right)$. These, like whorls, have two triradii and are characterized by high ridge counts.

The mean number of whorls in the four patients 


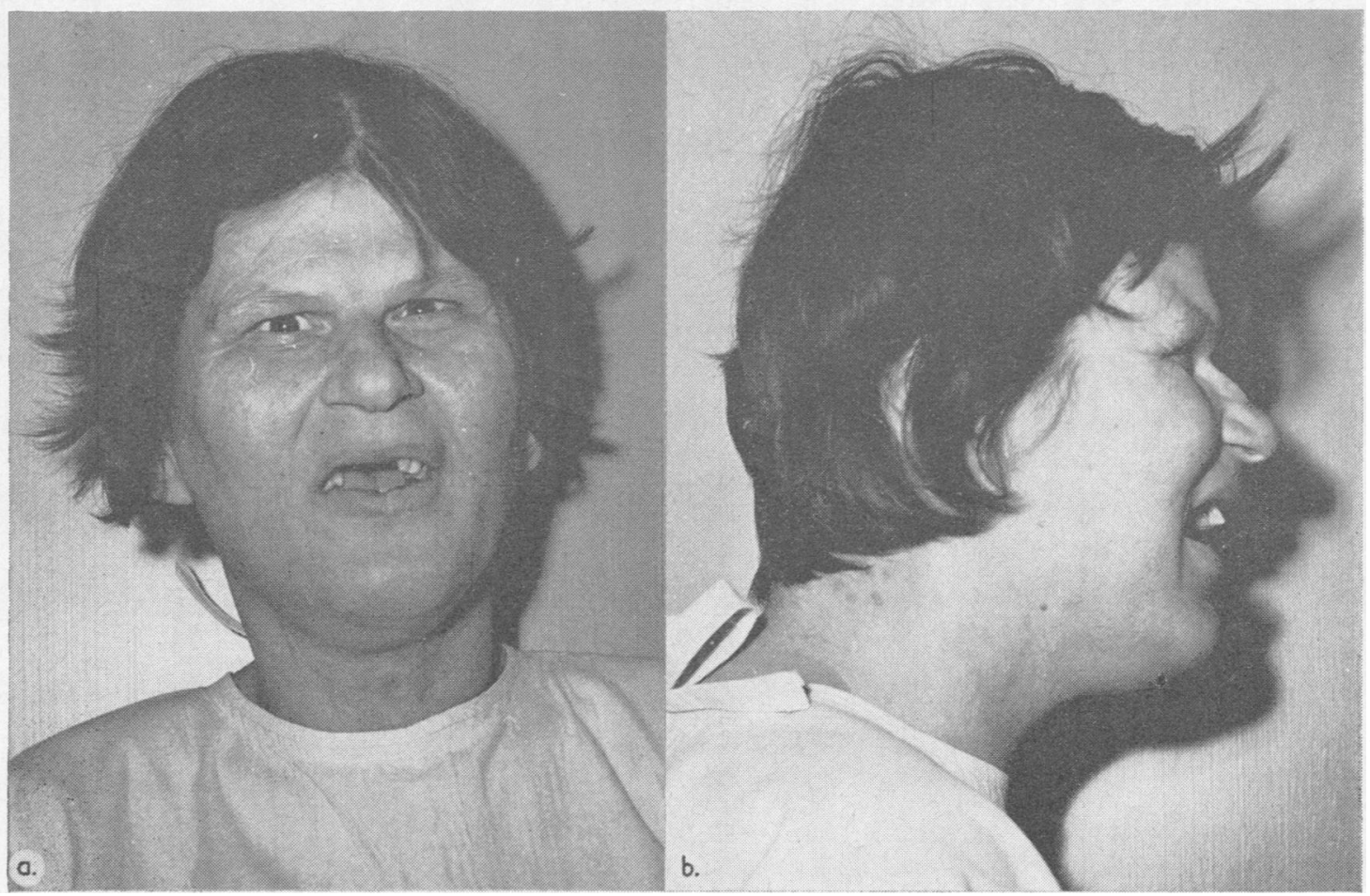

FIG. 5a. Case II.4 at the age of 42 showing mild hypoterlorism and a carp-shaped mouth. FIG. 5b. Side view of case II.4 demonstrating mid-facial retraction.

who had inherited the der(18) chromosome only (II.4, II.5, II.6, and III.10) was $8.7 \pm 1.5$ (mean \pm SD) which is significantly increased over the mean for the population $(t=8.2,3 \mathrm{df} ; p<0.01)$. The mean number of whorls for five patients carrying the balanced ins $(11 ; 18)$ was $4 \cdot 6 \pm 3 \cdot 0$, which does not differ significantly from the normal $(t=1 \cdot 46,4 \mathrm{df}$; $0.50<p<0.10)$, or from the $\operatorname{der}(18)$ patients $(t=$ $2.01,6 \mathrm{df} ; 0.10<\mathrm{p}<0.05)$. The mean total ridge count (TRC) was $170 \pm 11$ for $\operatorname{der}(18)$ and $197 \pm 41$ for ins $(11 ; 18)$, which are not significantly different $(t=1.30,5 \mathrm{df} ; 0.50<p<0 \cdot 10)$. However, both are significantly elevated over the population mean $(t=6.02,3$ df; $p<0.01$ and $t=3.2,4 d f ; 0.01<p<$ $0 \cdot 05$, respectively).

\section{Genetic markers}

Quantitative studies. Levels of IgA, IgM, and IgG obtained for II.4, II.5, II.6, and II.9 are summarized in Table II. These show the immunoglobulin levels to be normal or increased in these individuals.

Qualitative studies. Phenotypes of a number of red cell enzymes, serum proteins, and blood groups of the available family members were determined; these results have been summarized in the Appendix I. None of the alleles or haplotypes associated with any of the gene loci examined was found to segregate with either the $\operatorname{der}(11)$ or the der(18) chromosome. All individuals with the der(18) (II.4, II.5, II.6, and III.10) were found to have the Pep A 8-1 phenotype and, hence, the Pep $A^{8}$ Pep $A^{1}$ genotype (see below).

\section{Discussion}

Insertions which result from three chromosome breaks (Hamerton, 1971), are less common in human populations than reciprocal translocations which only require two breaks. In Drosophila, insertions have been induced but are relatively rare in comparison to reciprocal translocations (Lindsley and Grell, 1968). The introduction of chromosome banding techniques for the study of human chromosomes, will allow the different types of chromosome rearrangements to be distinguished in human populations. In a series of structural rearrangements ascertained in various ways, and in 


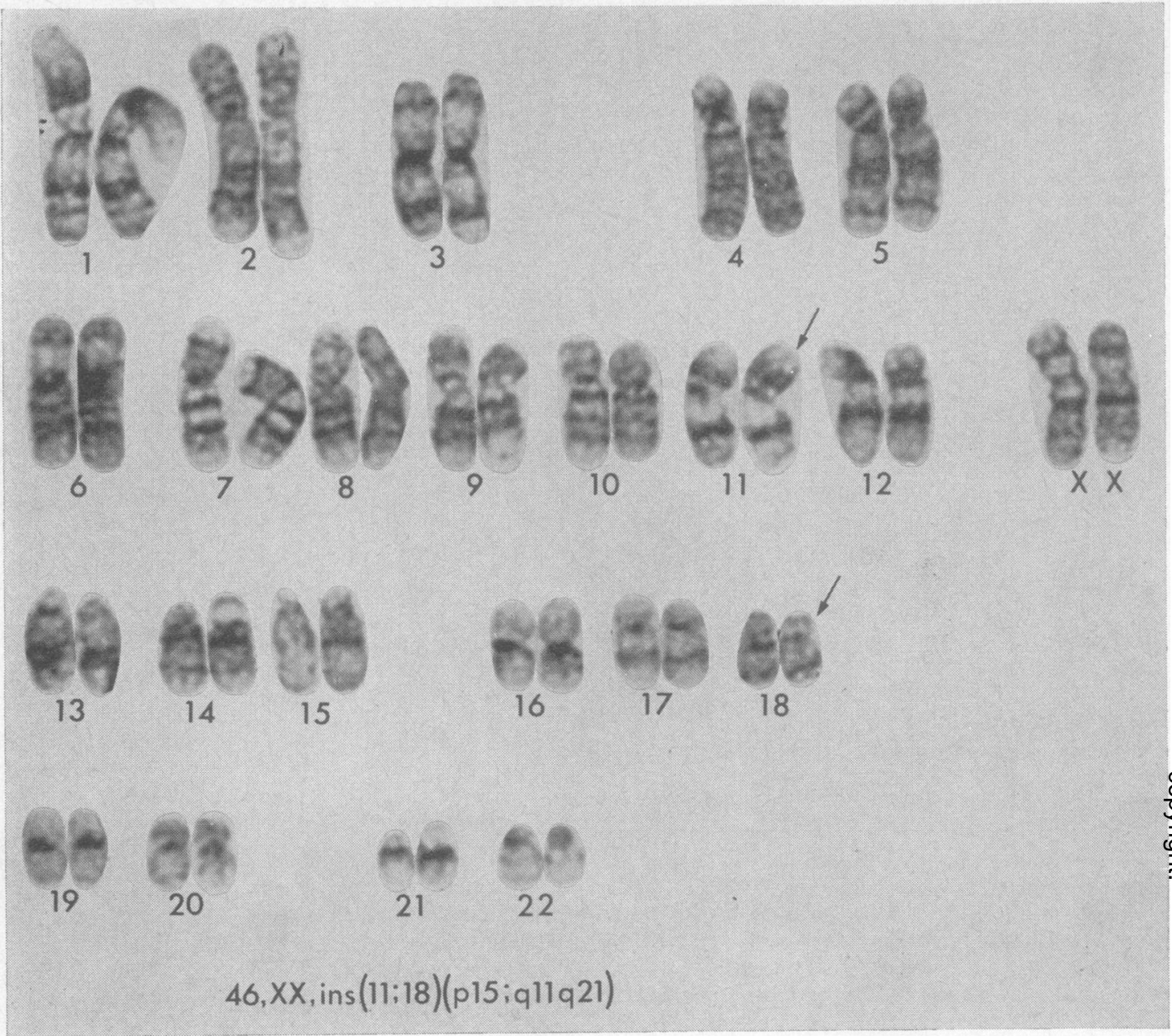

FIG. 6. A karyotype (case II.17) showing balanced insertion between chromosome Nos. 11 and 18: 46,XX,ins(11;18)(p15;q11q21).

which break points had been determined by banding (Jacobs et al, 1974), 58 were Robertsonian translocations, 53 reciprocal translocations, and 10 inversions; none were insertions. In a smaller series ascertained in a newborn survey, $J$. $L$. Hamerton (unpublished data) observed two insertions in 26 balanced rearrangements. One of these was the present family and the other an ins(12; 10). Thus, while two break rearrangements occur with a frequency of about 1 in 500 newborn infants, (J. L. Hamerton, unpublished data; Jacobs et al 1973/1974), insertions and other three break rearrangements are probably at least 10 times less frequent.

A few other families with this type of three break rearrangement have been described. Gray et al $\stackrel{\frac{0}{\sigma}}{\frac{\partial}{2}}$ (1972) described an ins $(4 ; 1)$, Grace, Sutherland, and 3 Bain (1972) an ins(3;7), and Shapiro and Warburton $(1972)$ an ins $(2 ; 12)$ in a mother of two mentally retarded children who had inherited the $\bigcirc$ der(12). Recently, Rethoré et al (1972) described a family in which there were three malformed sibs in which an ins(7;3)(q31;p21p26) was segregating. The present family was ascertained through a re- $\sigma$ tarded child with a balanced chromosome comple- N ment (III.6) who was referred to our department for $N$ genetic evaluation. At about this time III.10 was born and was studied routinely in a newborn chromosome survey and shown to have a $46, \mathrm{XX}, 18 \mathrm{q}$ complement on orcein staining. 


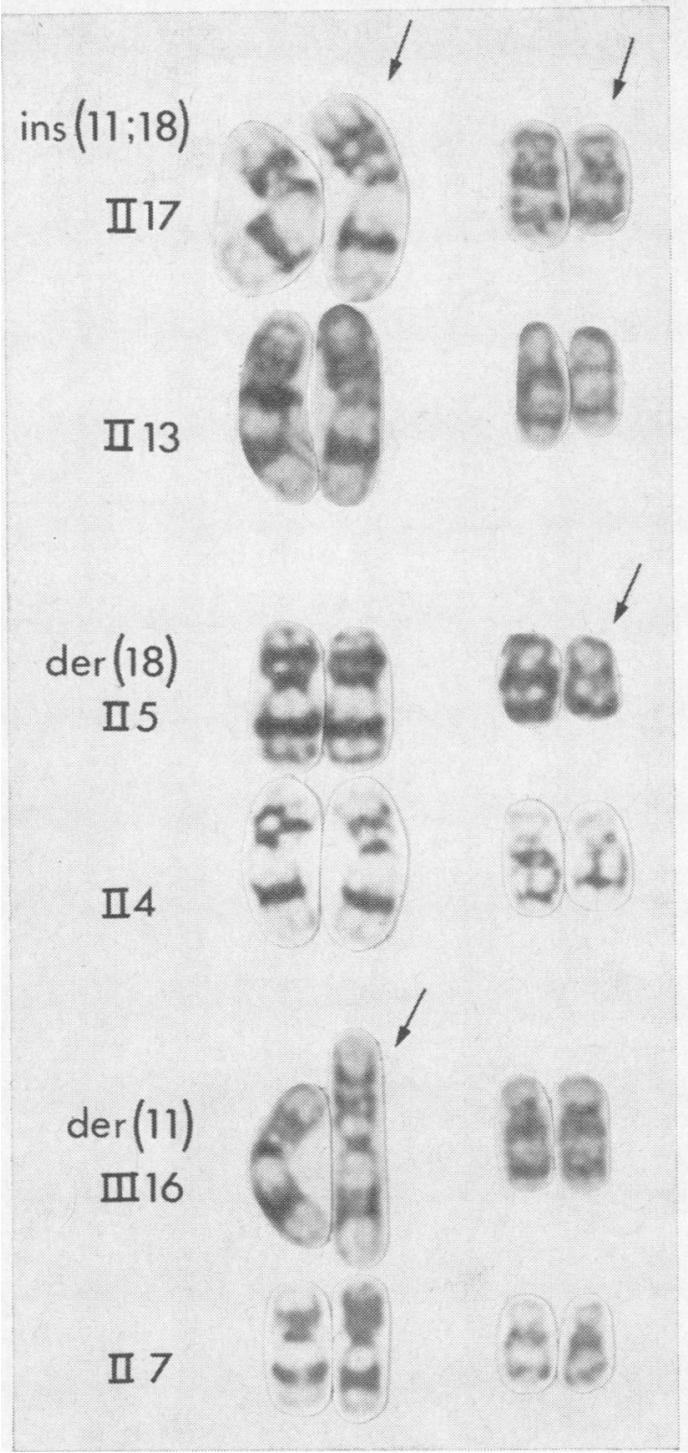

FIg. 7. Partial karyotypes showing chromosome 11 and 18. Balanced insertion (II.17 and 13), [ins $(11 ; 18)(\mathrm{p} 15 ; \mathrm{q} 11 \mathrm{q} 21)]$. der (18) (II.5 and 4), [der(18)ins(11;18)(p15;q11q21)pat]. $\operatorname{der}(11)(\mathrm{q} 11 \mathrm{q} 21)$ (III.16 and II.7), [der(11),ins(11;18)(p15;q11q21)pat].

In the present family, a three break insertional type rearrangement has been shown to be segregating. This resulted from the deletion of an interstitial segment of chromosome 18(q11q21) and its insertion into a breakpoint at p15 of chromosome 11 (Fig. 8). The most likely meiotic configuration for such an insertion are two unequal bivalents which would segregate at random and would result in equal numbers of gametes, carrying either the normal chromosomes 11 and 18, the $\operatorname{der}(11)$ and $\operatorname{der}(18)$, or either of the two derivative chromosomes along with the complementary normal chromosome (Fig. 8). In the unlikely event of crossing over within an interstitial inserted segment in a multivalent, all the gametes would be unbalanced; dicentric and acentric fragments would result, and might be one reason for the relatively high frequency of spontaneous abortions observed in some sibships.

At the present time, chromosome studies have not been possible on six subjects. Seventeen individuals have been studied. Eight of these had balanced heterozygous karyotypes; four had inherited the $\operatorname{der}(18)$, three the $\operatorname{der}(11)$, and two had normal karyotypes.

The four subjects (II.4, II.5, II.6, and III.10), who had inherited the $\operatorname{der}(18)$ and are deficient for an interstitial segment of chromosome 18, have some features of the 18q - syndrome (Lurie and Lazjuk, 1972). Table III lists the more frequent clinical features of this syndrome and compares these with the major clinical features shown by our $\operatorname{der}(18)$ patients. Examination of this table shows that the $18 q$ - condition has a rather variable phenotype. The major clinical features of our subjects include mental retardation (3/4, one-III.10-too young to assess), microcephaly (3/4), abnormal ears (4/4), mid-face retraction (3/4), carp-shaped mouth $(2 / 4)$, high arched palate $(2 / 4)$, and a high frequency of whorls or complex digital patterns (4/4). The major reasons for the observed variability in the 'deletion' syndromes have been discussed (Hamerton, 1971) and include variability in the type of chromosome abnormality and the amount of chromosome material deleted. In the past, conventional staining methods have simply allowed the detection of an 18q-; the use of banding will allow the identification of the deleted region, and in many cases will allow a distinction to be made between a balanced and an unbalanced karyotype. In the present family this distinction was made by using G-banding, but could not be detected by conventional means.

The digital patterns are of interest in this family and are characterized by a high frequency of whorls and complex patterns and a high total ridge count (TRC). Examination of the data suggests that subjects with an apparently balanced karyotype [ins $(11 ; 18)]$ show a significant increase in TRC; however, only those patients who have inherited the der(18) chromosome, and thus have an interstitial deletion, have a significantly raised frequency of 
TABLE I

DERMATOGLYPHIC FINDINGS IN THE PROPOSITUS AND HIS FAMILY

\begin{tabular}{|c|c|c|c|c|c|c|c|c|c|c|c|c|c|c|c|}
\hline \multirow[b]{2}{*}{ Case } & \multirow[b]{2}{*}{ Sex } & \multirow{2}{*}{$\underset{(y \mathbf{r})}{\underset{\text { Age at }}{\text { Examination }}}$} & \multicolumn{10}{|c|}{ Digital Patterns } & \multirow[b]{2}{*}{$\begin{array}{l}\text { No. of } \\
\text { Whorls* }\end{array}$} & \multirow[b]{2}{*}{$\begin{array}{l}\text { Total } \\
\text { Ridge } \\
\text { Countt }\end{array}$} & \multirow[b]{2}{*}{$\begin{array}{c}\text { atd Angles } \\
\text { (combined left } \\
\text { and right values) } \ddagger\end{array}$} \\
\hline & & & V & IV & Left & II & I & I & II & Righ & IV & V & & & \\
\hline $\begin{array}{l}\text { III.6 } \\
\text { (propositus) } \\
\text { I.16 } \\
\text { II.4 } \\
\text { II.5 } \\
\text { II.6 } \\
\text { II.9 } \\
\text { II.15 } \\
\text { II.17 } \\
\text { II.10 } \\
\text { III.3 } \\
\text { III.10 }\end{array}$ & $\begin{array}{l}\mathbf{M} \\
\mathbf{M} \\
\mathbf{F} \\
\mathbf{M} \\
\mathbf{M} \\
\mathbf{M} \\
\mathbf{F} \\
\mathbf{F} \\
\mathbf{F} \\
\mathbf{F} \\
\mathbf{F}\end{array}$ & $\begin{array}{l}2 \text { yr } 4 \text { mth } \\
84 \\
42 \\
40 \\
38 \\
33 \\
26 \\
23 \\
24 \\
3 \text { yr } 9 \text { mth } \\
8 \text { mth }\end{array}$ & $\begin{array}{l}\mathbf{L}^{\mathbf{u}} \\
\mathbf{L}^{\mathbf{u}} \\
\mathbf{W}^{\mathbf{d}} \\
\mathbf{W}^{\mathbf{d}} \\
\mathbf{W}^{\mathbf{s}} \\
\mathbf{L}^{\mathbf{u}} \\
\mathbf{L}^{\mathbf{u}} \\
\mathbf{W}^{\mathbf{s}} \\
\mathbf{L}^{\mathbf{u}} \\
\mathbf{L} \mathbf{u} \\
\mathbf{L}^{\mathbf{u}}\end{array}$ & $\begin{array}{l}L^{u} \\
L^{u} \\
W^{0} \\
W^{o} \\
W^{o} \\
W^{d} \\
L^{u} \\
W^{d} \\
L^{u} \\
L^{u} \\
W^{s}\end{array}$ & $\begin{array}{l}\mathbf{L}^{\mathbf{u}} \\
\mathbf{W}^{\mathbf{d}} \\
\mathbf{W}^{\circ} \\
\mathbf{L}^{\mathbf{u}} \\
\mathbf{W}^{\mathbf{o}} \\
\mathbf{L u}^{\mathbf{u}} \\
\mathbf{L} \mathbf{u} \\
\mathbf{W}^{\mathbf{d}} \\
\mathbf{W}^{\mathbf{s}} \\
\mathbf{L}^{\mathbf{u}} \\
\mathbf{W}^{\circ}\end{array}$ & $\begin{array}{l}W^{d} \\
W^{d} \\
W^{0} \\
W^{0} \\
W^{0} \\
W^{\mathbf{s}} \\
L^{u} \\
W^{d} \\
W^{\mathbf{s}} \\
L^{u} \\
W^{\circ}\end{array}$ & $\begin{array}{l}\mathbf{L}^{\mathbf{u}} \\
\mathbf{L}^{\mathbf{u}} \\
\mathbf{W}^{\mathbf{d}} \\
\mathbf{W}^{\mathbf{W}} \\
\mathbf{W}^{\mathbf{d}} \\
\mathbf{W}^{\mathbf{d}} \\
\mathbf{L}_{\mathbf{u}}^{\mathbf{u}} \\
\mathbf{W}^{\mathbf{s}} \\
\mathbf{L}^{\mathbf{u}} \\
\mathbf{L}^{\mathbf{u}} \\
\mathbf{W}^{\mathbf{o}}\end{array}$ & $\begin{array}{l}W^{d} \\
W^{d} \\
W^{d} \\
W^{o} \\
W^{o} \\
W^{d} \\
W^{d} \\
W^{d} \\
\mathbf{L}^{\mathbf{u}} \\
\mathbf{L}^{u} \\
\mathbf{W}^{d}\end{array}$ & $\begin{array}{l}W^{d} \\
W^{d} \\
W^{d} \\
W^{s} \\
W^{d} \\
W^{d} \\
\mathbf{L}^{\mathbf{u}} \\
\mathbb{W}^{d} \\
W^{\mathbf{s}} \\
\mathbf{L}^{\mathbf{u}} \\
\mathbf{W}^{0}\end{array}$ & $\begin{array}{l}\mathbf{L}^{\mathbf{u}} \\
\mathbf{L}_{\mathbf{W}}^{\mathbf{u}} \\
\mathbf{W}^{\circ} \\
\mathbf{L u}^{\mathbf{u}} \\
\mathbf{W}^{\mathbf{o}} \\
\mathbf{L u}^{\mathbf{u}} \\
\mathbf{L}^{\mathbf{u}} \\
\mathbf{W}^{\mathbf{d}} \\
\mathbf{W}^{\circ} \\
\mathbf{L u}^{\mathbf{u}} \\
\mathbf{W}^{\circ}\end{array}$ & $\begin{array}{l}\mathbf{L}^{\mathbf{u}} \\
\mathbf{L}^{\mathbf{u}} \\
\mathbf{W}^{\circ} \\
\mathbf{W}^{\circ} \\
\mathbf{W}^{\mathbf{s}} \\
\mathbf{W}^{\mathbf{d}} \\
\mathbf{L u}^{\mathbf{u}} \\
\mathbf{W}^{\mathbf{o}} \\
\mathbf{W}^{\circ} \\
\mathbf{L u}^{\mathbf{u}} \\
\mathbf{W}^{\circ}\end{array}$ & 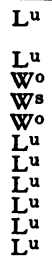 & $\begin{array}{r}3 \\
4 \\
4 \\
10 \\
8 \\
10 \\
6 \\
1 \\
9 \\
5 \\
0 \\
7\end{array}$ & $\begin{array}{l}193 \\
205 \\
161 \\
160 \\
177 \\
225 \\
125 \\
226 \\
173 \\
154 \\
182\end{array}$ & $\begin{array}{r}97^{\circ} \\
85^{\circ} \\
90^{\circ} \\
95^{\circ} \\
80^{\circ} \\
86^{\circ} \\
79^{\circ} \\
85^{\circ} \\
100^{\circ} \\
104^{\circ} \\
93^{\circ}\end{array}$ \\
\hline
\end{tabular}

$\mathbf{L}^{\mathrm{u}}=$ ulnar loop; $\mathrm{W}^{\mathrm{d}}=$ double loop or 'complex pattern'; $\mathrm{W}^{\mathrm{o}}=$ circular whorl; $\mathrm{W}^{\mathrm{s}}=$ spiral whorl.

Normal values (Holt, 1968)

* Mean no. of whorls 2.6 (British population 1000 ot and + pooled).

+ Mean for British males 145.18; SD $50 \cdot 49$.

$\begin{array}{ll}\text { Mean for British females } 126.97 \text {; SD } 52.33 \text {. } \\ \text { Pooled estimate } & 136.07 \text {; SD } 51 \cdot 41 \text {. }\end{array}$

¥ Mean atd $^{\circ}$ for males $\quad 92.5^{\circ}$; SD 14.2 (infants).

88.2 $2^{\circ}$; SD 15.9 (school children).

$85 \cdot 0^{\circ}$; SD $15 \cdot 3$ (adults).

Mean $a^{\circ} d^{\circ}$ for females $97.5^{\circ}$; SD 19.6 (infants).

89.8 $8^{\circ}$; SD 17.5 (school children).

$85.9^{\circ}$; SD $15 \cdot 7$ (adults).

TABLE II

QUANTITATIVE VALUES OF IMMUNOGLOBULINS (mg\%)

\begin{tabular}{l|c|c|c|c|c}
\hline Case & Source & $\begin{array}{c}\text { Age } \\
(\mathbf{y r})\end{array}$ & $\begin{array}{c}\text { IgG } \\
(\mathrm{N}=600-1700)\end{array}$ & $\begin{array}{c}\text { IgA } \\
(\mathrm{N}=70-400)\end{array}$ & $\begin{array}{c}\text { IgM } \\
(\mathrm{N}=80-300)\end{array}$ \\
\hline II.4 & Serum & 42 & 1900 & 370 & 590 \\
II.5 & Serum & 40 & 1750 & 500 & 340 \\
II.6 & Serum & 37 & 1350 & 640 & 440 \\
II.9 & Serum & 33 & 1100 & 280 & 340 \\
\hline
\end{tabular}

$\mathrm{N}=$ Normal values.

TABLE III

CLINICAL FINDINGS IN PARTIAL 18 LONG-ARM DELETION

\begin{tabular}{|c|c|c|c|c|c|}
\hline & \multirow{2}{*}{$\begin{array}{c}\text { Percent } \\
\text { of } \\
\text { Cases* }\end{array}$} & \multicolumn{4}{|c|}{ Present Cases } \\
\hline & & II.4 & II.5 & II.6 & III.10 \\
\hline $\begin{array}{l}\text { Mental retardation } \\
\text { Microcephaly } \\
\text { Prominent antihelix } \\
\text { and/or antitragus } \\
\text { Narrow ear canals } \\
\text { Mid-face retraction } \\
\text { Carp-shaped mouth } \\
\text { Fundoscopic } \\
\text { abnormalities } \\
\text { High (or cleft) palate } \\
\text { Many whorls ( > 5) } \\
\text { Sub-acromial dimples } \\
\text { Genital anomalies } \\
\text { Fusiform fingers } \\
\text { Abnormalities of foot }\end{array}$ & $\begin{array}{l}100 \\
76 \\
65 \dagger \\
38 \\
62 \\
50 \ddagger \\
29 \\
42 \\
51 \dagger \\
54 \ddagger \\
44 \\
100 * * \\
36\end{array}$ & $\begin{array}{l}+ \\
+ \\
+ \\
+ \\
+ \\
= \\
\pm \\
= \\
=\end{array}$ & $\begin{array}{l}+ \\
+ \\
+ \\
- \\
= \\
+ \\
= \\
-\end{array}$ & $\begin{array}{l} \pm \\
+ \\
\overline{+} \\
- \\
- \\
\pm \\
- \\
-\end{array}$ & $\begin{array}{c}\text { Not yet evident } \\
+ \\
+ \\
\overline{+} \\
+ \\
- \\
+ \\
+ \\
= \\
= \\
-\end{array}$ \\
\hline
\end{tabular}

+ present; - not present.

* Adapted from Lurie and Lazjuk (1972).

t Data from Wertelecki and Gerald (1971).

¥ Data from de Grouchy (1969).

* Data from Rudd and LaMarche (1971). 'complex digital patterns'. One subject (III.3) who had inherited the der(11) and had therefore a triplication of the inserted region, had no whorls? These observations suggest that a high TRC and high number of whorls are at least partially inde pendent of each other, contrary to the view of Parker? et al (1972). Abnormal dermatoglyphics have been reported in other individuals with rearrangements involving chromosome 18 (Valdmanis et al, 1967; Hoehn, Sander, and Sander, 1971; Jacobsen et al, 1971; Rudd and LaMarche, 1971; Lurie and Lazjuk, 1972; Parker et al, 1972; Gouw et al, 1973). In particular others have reported an increase in whorls or complex patterns in the $18 \mathrm{q}$ - syndrome (Valdmanis et al, 1967; Hoehn et al, 1971; Jacobsen et al, 1971). High TRCs have also been recorded in a few subjects with a balanced rearrangement (Jacobsen et al, 1971), although in that family increased TRC's were also found in members who had normal chromosomes.

The significance of these observations is by no means clear. De Grouchy (1965) postulated that a distal part of $18 \mathrm{q}$ was involved in the determination of whorl count. It seems unlikely, however, that we are dealing with a specific chromosome region. Rather, the well-known effect of chromosome imbalance on dermatoglyphic patterns is the result of non-specific alterations in developmental processes which lead to these alterations in pattern. The most surprising observation is the increase in TRC 

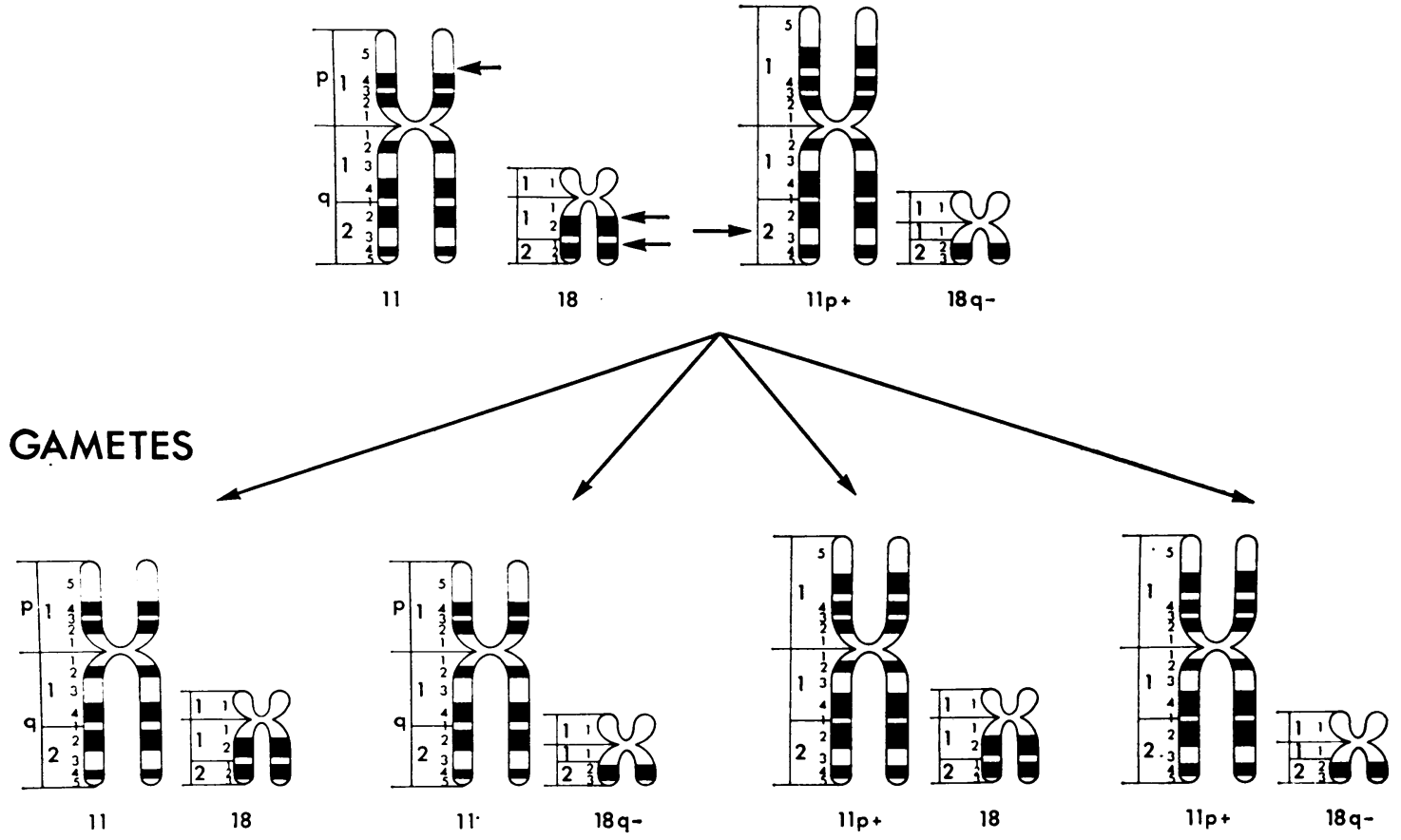

FIG. 8. Diagram to illustrate the nature of the rearrangement which has occurred in this family and the gametes which would result from the pairing of two unequal bivalents.

seen in the apparently balanced heterozygotes and further studies are required here, on both normal and balanced subjects, to determine whether this is a generalized heritable increase in these families, or if it is really due to the movement of a chromosome segment from one region of the genome to another.

There have been several reports of the absence of serum IgA in patients with an $18 \mathrm{q}-$ or an $18 \mathrm{r}$. This had led to the suggestion that the long arm of chromosome 18 may be involved in the control of IgA synthesis (Feingold et al, 1969; Finley et al, 1969; Masterson and Law, 1969; Stewart et al, 1970; Rudd and LaMarche, 1971). The finding of normal or raised IgA levels in three patients carrying the $\operatorname{der}(18)$ (II.4, II.5, II.6) and one subject with a balanced karyotype (II.9) neither supports nor refutes this hypothesis, but simply suggests that 'the IgA centre' if present on chromosome 18, does not lie in the (18)(q11q21) region.

The association of $18 \mathrm{q}$ - with a syndrome of severe mental retardation and a spectrum of clinical findings in II.4, II.5, and II.6 is clear, and patients with similar clinical findings have been reported previously (Wertelecki and Gerald, 1971; Lurie and Lazjuk, 1972). In the present family the deletion resulted from the segregation of derivative chromo- somes, formed as the result of a balanced insertion between chromosomes 11 and 18 . Three subjects (II.7, III.3, and III.16) have inherited the der(11) and so had a triplication of the inserted region from chromosome 18. Two of these appear mildly retarded (II.7 and III.16) while one (III.3) seems to be developing relatively normally; one subject (III.16) is a spastic quadriplegic, has frequent upper respiratory infections, slurring of speech, and a poor vocabulary for a child of four; whether any of these latter findings result from the chromosome abnormality is not certain. It is clear, however, that a deletion of this chromosome segment seems to have more deleterious consequences than its duplication.

Eight members of this family are carrying the balanced rearrangement; seven of these are mildly retarded or have low normal intelligence and one (III.6) is severely retarded. The significance of these findings is much less clear. This family comes from a poor environmental background and many members are still living in poor conditions and many of their children are emotionally deprived. It is impossible, therefore, to determine whether the low intelligence of most members of the family is due to 'position effect', resulting from the shift of a chromosome segment from one posi- 
tion in the genome to another, to a hidden imbalance not detectable by means available to us, or largely to environmental factors. It is interesting to note that II.2, the only adult member of the family who has normal chromosomes, also has the highest intelligence, although of course no definite conclusions can be drawn from this observation.

Genetic marker studies in families in which a marker chromosome is segregating have been used to assign particular gene loci to specific chromosomes or chromosome regions either by linkage analysis or by deletion mapping. Three autosomal loci have been localized using this approach: the Duffy blood group gene locus to the centromeric region of chromosome 1 (Donahue et al, 1968; Ying and Ives, 1968), the $\alpha$-haptoglobin gene locus to the long arm of chromosome 16 (Robson et al, 1969; Magenis, Hecht, and Lovrien, 1970) and the red cell acid phosphatase gene locus to the p23 $\rightarrow$ pter region of chromosome 2 (Ferguson-Smith et al, 1973). The assignment of a considerable number of gene loci to specific human chromosomes using somatic cell hybrids, combined with a precise identification of chromosomes (Ruddle, 1973), allows a greater use to be made of 'deletion mapping' to assign a gene locus to, or exclude it from, a specific chromosome region.

The previous assignment of the $\operatorname{Pep} A$ locus to chromosome 18 (Creagan et al, 1973; McAlpine et $a l, 1974)$, allowed the use of 'deletion mapping' in the present family. Four individuals who were shown to be deficient for (18)(q11q21) were also shown to be heterozygous at the $\operatorname{Pep} A$ locus and to have the genotype $P e p A^{8} P e p A^{1}$. This demonstration of heterozygosity for a locus known to be assigned to chromosome 18 , indicates that each of these individuals has two $\operatorname{Pep} A$ alleles so that the gene locus cannot be located in the deleted segment of chromosome 18, (18)(q11q21).

The authors wish to thank Dr G. Lowther and Dr L. $\mathrm{N}$. Young for permission to study their patients. We would also like to thank Dr W. Grant of the Child Development Clinic for developmental assessment of the propositus; Dr Betty Jones of Port Allice, British Columbia, for information about part of the family; Miss Marion Lewis of the Rh Laboratory for blood grouping analysis; Dr D. W. Cox, Department of Paediatrics, University of Toronto and the Research Institute, The Hospital for Sick Children for the $\alpha_{1}$ antitrypsin analysis; Dr A. G. Steinberg, Department of Biology, Case Western Reserve University, Cleveland, Ohio, for the $\mathrm{Gm}$ and Inv analysis; Dr L. Weitkamp, Department of Anatomy, Division of Genetics, The University of Rochester School of Medicine and Dentistry, Rochester, New York, for the Gc, Hp, Tf, and C'3 analysis; and Dr S. Paraskevas of the Manitoba Cancer
Treatment and Research Foundation for immunoglobulin analysis. We acknowledge the help of the staff of the Manitoba School for Retardates and the expert technical assistance of Ms Linda Karmarnicki and Ms Holly Maledy. We acknowledge financial support from $\vec{\Rightarrow}$ the Children's Hospital Research Foundation of Winnipeg, Inc, the Medical Research Council of Canada (MRC Operating Grant MA4458) and the Department of Health and Welfare (Grant No. PH606-7-224).

\section{REFERENCES}

Caspersson, T., Zech, L., and Johansson, C. (1970). Differential binding of alkylating fluorochromes in human chromosomes. Experimental Cell Research, 60, 315-319.

Creagan, R., Tischfield, J., McMorris, F. A., Chen, S., Hirschi, M., Chen, T. R., Ricciuti, F., and Ruddle, F. H. (1973). Assignment of the genes for human peptidase $A$ to chromosome 18 and cytoplasmic glutamic oxaloacetate transaminase to chromosome 10 using somatic-cell hybrids. Cytogenetics and Cell Genetics, 12, 187-198.

De Grouchy, J. (1965). Chromosome 18: A topologic approach. Fournal of Pediatrics, 66, 414-431.

De Grouchy, J. (1969). The $18 \mathrm{p}-, 18 \mathrm{q}-$ and $18 \mathrm{r}$ syndromes. Birth Defects: Original Article Series, 5, pt. 5, 74-87. National Foundation-March of Dimes, New York.

De Grouchy, J., Royer, P., Salmon, C., and Lamy, M. (1964). Délétion partielle des bras longs du chromosome 18. Pathologie et Biologie, 12, 579-582.

Donahue, R. P., Bias, W. B., Renwick, J. H., and McKusick, V. A. (1968). Probable assignment of the Duffy blood group locus to (1) chromosome 1 in man. Proceedings of the National Academy of Science, 61, 949-955.

Feingold, M., Schwartz, R. S., Atkins, L., Anderson, R., Bartsocas, C. S., Page, D. L., and Littlefield, J. W. (1969). IgA deficiency associated with partial deletion of chromosome 18. America? fournal of Diseases of Children, 117, 129-136.

Ferguson-Smith, M. A., Newman, B. F., Ellis, P. M., Thomson, is M. G., and Riley, I. D. (1973). Assignment by deletion of humaty red cell acid phosphatase gene locus to the short arm of chromosome 2. Nature New Biology, 243, 271-273.

Finley, S. C., Cooper, M. D., Finley, W. H., Uchida, I. A., Noto, T. A., and Roddam, R. F. (1969). Immunological profile in a chromosome 18 deletion syndrome with IgA deficiency. Fournal of Medical Genetics, 6, 388-393.

Gouw, W. L., Ten Kate, L. P., and Anders, G. J. P. A. (1973). A case of $18 q-$ in a family with a translocation $t(6 p+; 18 q-)$, identified by the Giemsa-banding technique. Humangenetik, 19, 123126.

Grace, E., Sutherland, G. R., and Bain, A. D. (1972). Familial insertional translocation. Lancet, 2, 231.

Gray, J. E., Syrett, J. E., Ritchie, K. M., and Elliott, W. D. (1972). An interstitial translocation: chromosome No. $1 \mathrm{p}$ to $4 \mathrm{q}$. Lancet 2, 92-93.

Hamerton, J. L. (1971). Human Cytogenetics, vol. 1, p. 239. Academic Press, New York.

Hamerton, J. L., Ray, M., and Douglas, G. R. (1973). Chromosome banding techniques in clinical cytogenetics: Report of four cases irresolvable by conventional methods. In Nobel Symposium 23Chromosome Identification, ed. by T. Caspersson and L. Zech, pp. 209-213. Nobel Foundation, Stockholm; Academic Press, London and New York.

Hoehn, H., Sander, C., and Sander, L. Z. (1971). Aneusomie de recombinaison: rearrangement between paternal chromosomes 4 and 18 yielding offspring with features of the $18 \mathrm{q}-$ syndrome. Annales de Génétique, 14, 187-192.

Holt, S. B. (1968). The Genetics of Dermal Ridges. Thomas, Springfield, Illinois.

Jacobs, P. A., Melville, M., Ratcliffe, S., Keay, A. J., and Syme, J. (1973/1974). A cytogenetic survey of 11,680 newborn infants. Annals of Human Genetics, 37, 359-376.

Jacobs, P. A., Buckton, K. E., Cunningham, C., and Newton, M. (1974). An analysis of the break points of structural rearrangements in man. fournal of Medical Genetics, 11, 50-64. 
Jacobsen, P., Mikkelsen, M., Niebuhr, E., and De Grouchy, J. (1971). A case of $18 \mathrm{q}-$ in a $\mathrm{t}(18 \mathrm{q}-; 6 \mathrm{p}+)$ family. Annales de Génétique, 14, 41-48.

Law, E. M. and Masterson, J. G. (1966). Partial deletion of chromosome 18. Lancet, 2, 1137.

Lewis, W. H. P. (1973). Common polymorphism of Peptidase A. Electophoretic variants associated with quantitative variation of red cell levels. Annals of Human Genetics, 36, 267-271.

Lindsley, D. L. and Grell, E. H. (1968). Genetic Variations of Drosophila Melanogaster. Carnegie Institution, Washington.

Lurie, I. W. and Lazjuk, G. I. (1972). Partial monosomies 18. Review of cytogenetical and phenotypical variants. Humangenetik, 15, 203-222.

McAlpine, P. J., Gee, P. A., Douglas, G. R., and Hamerton, J. L. (1974). Localization of the structural gene for human peptidase A to chromosome 18. In: Proceedings of the First International Workshop on Human Gene Mapping. Birth Defects: Original Article Series, 8, No. 3, 1974, pp. 128-129. National Foundation - March of Dimes, New York.

Magenis, R. E., Hecht, F., and Lovrien, E. W. (1970). Heritable fragile site on chromosome 16: probable localization of haptoglobin locus in man. Science, 170, 85-87.

Masterson, J. G. and Law, E. M. (1969). IgA and partial deletions of chromosome 18. Irish fournal of Medical Science, 2, 265-267.

Paris Conference (1971). Standardization in human cytogenetics. Birth Defects: Original Article Series, 8, No. 7, 1972. The National Foundation-March of Dimes, New York.

Parker, C. E., Mavalwala, J., Koch, R., Hatashita, A., and Derencseni, A. (1972). The syndrome associated with the partial deletion of the long arms of chromosome $18(18 q-)$. California Medicine, 117, No. 4, 65-71.

Rethoré, M. O., Lejeune, J., Carpentier, S., Prieur, M., Dutrillaux, B., Seringe, P. H., Rossier, A., and Job, J. C. (1972). Trisomie pour la partie distale du bras court du chromosome 3 chez trois germains. Premier exemple d'insertion chromosomique: ins $(7 ; 3)$ (q31;p21p26). Annales de Génétique, 15, 159-165.

Robson, E. B., Polani, P. E., Dart, S. J., Jacobs, P. A., and Renwick, J. H. (1969). Probable assignment of the alpha locus of haptoglobin to chromosome 16 in man. Nature, 223, 1163-1165.

Rudd, N. L. and LaMarche, P. H. (1971). Gene deletion and duplication effects on phenotype and gamma globulin levels. fournal of Medical Genetics, 8, 97-106.

Ruddle, F. H. (1973). Linkage analysis in man by somatic cell genetics. Nature, 242, 165-169.

Seabright, $M$. (1971). A rapid banding technique for human chromosomes. Lancet, 2, 971-972.

Shapiro, L. R. and Warburton, D. (1972). Interstitial translocation in Man. Lancet, 2, 712-713.

Stewart, J. M., Go, S., Ellis, E., and Robinson, A. (1970). Absent IgA and deletions of chromosome 18. Fournal of Medical Genetics, 7, 11-19.

Sumner, A. T., Evans, H. J., and Buckland, R. A. (1971). New technique for distinguishing between human chromosomes. Nature New Biology, 232, 31-32.

Valdmanis, A., Pearson, G., Siegel, A. E., Hoeksema, R. H., and Mann, J. D. (1967). A pedigree of 4/18 translocation chromosomes with type and countertype partial trisomy and partial monosomy for chromosome 18. Annales de Génétique, 10, 159166.

Wang, H. C. and Federoff, S. (1972). Banding in human chromosomes treated with trypsin. Nature New Biology, 235, 52-53.

Wertelecki, W. and Gerald, P. S. (1971). Clinical and chromosomal studies of the 18q - syndrome. Fournal of Pediatrics, 78, 44-52.

Ying, K. L. and Ives, E. J. (1968). Asymmetry of chromosome number 1 pair in three generations of a phenotypically normal family. Canadian fournal of Genetics and Cytology, 10, 575-589. 
SUMMARY OF PHENOTYPES OF GENETICD

\begin{tabular}{|c|c|c|c|c|c|c|c|c|c|c|c|c|c|c|}
\hline \multirow[b]{2}{*}{$\begin{array}{c}\text { Pedigree } \\
\text { No. }\end{array}$} & \multirow[b]{2}{*}{ Sex } & \multicolumn{13}{|c|}{ Enzymes } \\
\hline & & Pep A & Pep B & Pep C & Pep D & $\mathrm{PGM}_{1}$ & G6PD & $6 \mathrm{PGD}$ & $\mathrm{AK}_{1}$ & PHI & GPT & $\mathrm{GOT}_{1}$ & $\mathrm{AcP}_{1}$ & ADA \\
\hline I.16 & $M$ & $8-1$ & 1 & 1 & 1 & 1 & B & A & 1 & 1 & 2 & 1 & $\mathrm{BA}$ & 1 \\
\hline $\begin{array}{l}\text { II.4 } \\
\text { II.5 } \\
\text { II.6 } \\
\text { II.7 } \\
\text { II.9 } \\
\text { II.10 } \\
\text { II.13 } \\
\text { II.14 } \\
\text { II.15 } \\
\text { II.17 }\end{array}$ & $\begin{array}{l}F \\
M \\
M \\
F \\
M \\
F \\
F \\
M \\
F \\
F\end{array}$ & $\begin{array}{c}8-1 \\
8-1 \\
8-1 \\
1 \\
8-1 \\
1 \\
\text { NT } \\
\text { NT } \\
1 \\
1\end{array}$ & $\begin{array}{c}1 \\
1 \\
1 \\
1 \\
1 \\
1 \\
\text { NT } \\
\text { NT } \\
1 \\
1\end{array}$ & $\begin{array}{c}1 \\
1 \\
1 \\
1 \\
1 \\
1 \\
\text { NT } \\
\text { NT } \\
1 \\
1\end{array}$ & $\begin{array}{c}1 \\
\text { NT } \\
1 \\
1 \\
1 \\
1 \\
\text { NT } \\
\text { NT } \\
1 \\
1\end{array}$ & $\begin{array}{l}1 \\
1 \\
1 \\
1 \\
1 \\
2 \\
1 \\
1 \\
1 \\
1\end{array}$ & $\begin{array}{c}\text { B } \\
\mathbf{B} \\
\mathbf{B} \\
\mathbf{B} \\
\mathbf{B} \\
\mathbf{N} \mathbf{T} \\
\mathbf{B} \\
\mathbf{B} \\
\mathbf{B} \\
\mathbf{B}\end{array}$ & $\begin{array}{c}\text { A } \\
\text { A } \\
\text { A } \\
\text { A } \\
\text { A } \\
\text { NT } \\
\text { A } \\
\text { A } \\
\text { A } \\
\text { A }\end{array}$ & $\begin{array}{l}1 \\
1 \\
1 \\
1 \\
1 \\
1 \\
1 \\
1 \\
1 \\
1\end{array}$ & $\begin{array}{c}1 \\
1 \\
1 \\
1 \\
1 \\
1 \\
\text { NT } \\
\text { NT } \\
1 \\
1\end{array}$ & $\begin{array}{c}2 \\
2 \\
2 \\
\text { NT } \\
2-1 \\
\text { NT } \\
2-1 \\
2 \\
2-1 \\
2\end{array}$ & $\begin{array}{l}1 \\
1 \\
1 \\
1 \\
1 \\
1 \\
1 \\
1 \\
1 \\
1\end{array}$ & $\begin{array}{c}\text { B } \\
\text { B } \\
\text { BA } \\
\text { BA } \\
\text { B } \\
\text { BA } \\
\text { B } \\
\text { A } \\
\text { BA } \\
\text { BA }\end{array}$ & $\begin{array}{c}1 \\
1 \\
1 \\
1 \\
1 \\
1 \\
\text { NT } \\
\text { NT } \\
1 \\
1\end{array}$ \\
\hline $\begin{array}{l}\text { III. } 3 \\
\text { III. } 6 \\
\text { III. } 10 \\
\text { III. } 14 \\
\text { III. } 16\end{array}$ & $\begin{array}{l}F \\
M \\
F \\
F \\
M\end{array}$ & $\begin{array}{l}8-1 \\
8-1 \\
8-1 \\
\text { NT } \\
\text { NT }\end{array}$ & $\begin{array}{c}1 \\
1 \\
1 \\
\text { NT } \\
\text { NT }\end{array}$ & $\begin{array}{c}1 \\
1 \\
1 \\
\text { NT } \\
\text { NT }\end{array}$ & $\begin{array}{c}1 \\
1 \\
1 \\
\text { NT } \\
\text { NT }\end{array}$ & $\begin{array}{c}2-1 \\
2-1 \\
2-1 \\
1 \\
1\end{array}$ & $\begin{array}{l}\mathbf{B} \\
\mathbf{B} \\
\mathbf{B} \\
\mathbf{B} \\
\mathbf{B}\end{array}$ & $\begin{array}{c}\text { A } \\
\text { A } \\
\text { A } \\
\text { BA } \neq \\
\text { A }\end{array}$ & $\begin{array}{l}1 \\
1 \\
1 \\
1 \\
1\end{array}$ & $\begin{array}{c}1 \\
1 \\
1 \\
\text { NT } \\
\text { NT }\end{array}$ & $\begin{array}{c}2-1 \\
2-1 \\
2-1 \\
2 \\
2-1\end{array}$ & $\begin{array}{l}1 \\
1 \\
1 \\
1 \\
1\end{array}$ & $\begin{array}{c}\mathbf{B A} \\
\mathbf{B} \\
\mathbf{B} \\
\mathbf{B}^{*} \\
\mathbf{B A}\end{array}$ & $\begin{array}{c}1 \\
1 \\
1 \\
\text { NT } \\
\text { NT }\end{array}$ \\
\hline
\end{tabular}

NT $=$ Not tested.

Samples were tested for $\operatorname{Gm}(1,2,3,5,6,13,14,17,21)$ and $\operatorname{Inv}(1)$.

All samples were $\mathrm{Lu}(\mathrm{a}-\mathrm{b}+)$ and $\mathrm{K}-\mathbf{k}+$. A number of other blood groups were tested which were uniformative. These results are avail-을

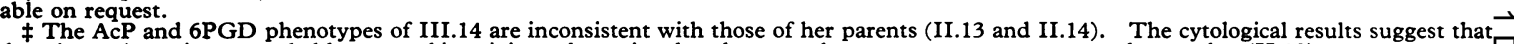
these inconsistencies are probably paternal in origin as the patient has the same chromosome rearrangement as her mother (II.13). 
I

MARKERS IN THE FAMILY

\begin{tabular}{|c|c|c|c|c|c|c|c|c|c|c|c|c|c|c|c|c|c|}
\hline \multicolumn{7}{|c|}{ Serum Proteins } & \multicolumn{11}{|c|}{ Blood Groupst } \\
\hline \multirow{2}{*}{ Gc } & \multirow{2}{*}{$\mathrm{Hp}$} & \multirow{2}{*}{ Tf } & \multirow{2}{*}{$C^{\prime} 3$} & \multirow{2}{*}{$\mathbf{P i}$} & \multirow{2}{*}{$\mathrm{Gm}^{*}$} & \multirow{2}{*}{ Inv } & \multirow{2}{*}{ ABO } & \multirow{2}{*}{ MNSs } & \multirow{2}{*}{$\mathbf{R h}$} & \multicolumn{2}{|c|}{ Fy } & \multicolumn{2}{|c|}{$\mathbf{J k}$} & \multirow{2}{*}{$\frac{\text { Le }}{a}$} & \multirow{2}{*}{$\frac{\text { Co }}{b}$} & \multirow{2}{*}{$\begin{array}{c}\text { Do } \\
\text { a }\end{array}$} & \multirow{2}{*}{$\mathbf{P}$} \\
\hline & & & & & & & & & & $\mathbf{a}$ & $\mathbf{b}$ & $\mathbf{a}$ & $\mathbf{b}$ & & & & \\
\hline $2-1$ & 2 & C & 2 & $\mathbf{M M}$ & $1,3,5,13,14,17,21$ & -1 & B & MSMS & $R_{1} R_{2}$ & + & + & - & + & - & NT & - & NT \\
\hline $\begin{array}{c}1 \\
1 \\
2-1 \\
2-1 \\
1 \\
1 \\
\text { NT } \\
\text { NT } \\
1 \\
1\end{array}$ & $\begin{array}{l}2 \\
2-1 \\
2 \\
2-1 \\
2-1 \\
2 \\
\text { NT } \\
\text { NT } \\
2-1 \\
2-1\end{array}$ & $\begin{array}{l}\text { C } \\
\text { C } \\
\text { C } \\
\text { C } \\
\text { C } \\
\text { NT } \\
\text { NT } \\
\text { C } \\
\text { C }\end{array}$ & \begin{tabular}{c|}
2 \\
2 \\
2 \\
2 \\
2 \\
$1-2$ \\
NT \\
NT \\
2 \\
2
\end{tabular} & $\begin{array}{l}\text { MM } \\
\text { MM } \\
\text { MM } \\
\text { MM } \\
\text { MM } \\
\text { MM } \\
\text { NT } \\
\text { NT } \\
\text { MM } \\
\text { MM }\end{array}$ & $\begin{array}{c}1,3,5,13,14,17,21 \\
3,5,13,14 \\
1,3,5,13,14,17,21 \\
1,3,5,13,14,17,21 \\
3,5,13,14 \\
3,5,13,14 \\
\text { NT } \\
\text { NT } \\
1,3,5,13,14,17,21 \\
3,5,13,14\end{array}$ & $\begin{array}{l}-1 \\
-1 \\
-1 \\
-1 \\
-1 \\
1 \\
\text { NT } \\
\text { NT } \\
-1 \\
-1\end{array}$ & $\begin{array}{c}\mathbf{A}_{1} \mathbf{B} \\
\mathbf{A}_{1} \mathbf{B} \\
\mathbf{B} \\
\mathbf{B} \\
\mathbf{B} \\
\mathbf{B} \\
\mathbf{A}_{1} \mathbf{B} \\
\underset{\mathbf{O}}{\mathbf{B}} \\
\underset{\mathbf{A}_{1} \mathbf{B}}{ }\end{array}$ & $\begin{array}{l}\text { MSMS } \\
\text { MSNS } \\
\text { MSNS } \\
\text { MSNS } \\
\text { MSMS } \\
\text { NSN' } \\
\text { MSMS } \\
\text { MSMS } \\
\text { MSNS } \\
\text { MSMS }\end{array}$ & $\begin{array}{l}R_{2} \mathbf{r} \\
R_{1} \mathbf{r} \\
R_{2} \mathbf{r} \\
R_{1} \mathbf{R}_{1} \\
R_{1} \mathbf{R}_{1} \\
R_{1} \mathbf{R}_{2} \\
\mathbf{R}_{1} \mathbf{r} \\
\mathbf{R}_{\mathbf{1}} \mathbf{r} \\
\mathbf{R}_{1} \mathbf{r} \\
\mathbf{R}_{\mathbf{2}} \mathbf{r} \\
\end{array}$ & $\begin{array}{l}+ \\
+ \\
+ \\
+ \\
+ \\
+ \\
+ \\
+\end{array}$ & $\begin{array}{l}+ \\
+ \\
+ \\
+ \\
+ \\
+ \\
+ \\
+ \\
+ \\
+\end{array}$ & $\begin{array}{l}- \\
\overline{+} \\
+ \\
+ \\
+ \\
+ \\
+ \\
+ \\
+\end{array}$ & $\begin{array}{l}+ \\
+ \\
+ \\
+ \\
+ \\
+ \\
+ \\
+ \\
+ \\
+\end{array}$ & $\begin{array}{l}\bar{z} \\
\bar{z} \\
\bar{t} \\
\bar{t} \\
\bar{t}\end{array}$ & $\begin{array}{l}\text { NT } \\
\text { NT } \\
\text { NT } \\
\text { NT } \\
= \\
= \\
\overline{-} \\
\text { NT }\end{array}$ & $\begin{array}{c}\text { NT } \\
\text { NT } \\
\text { NT } \\
+ \\
+ \\
+ \\
+ \\
+ \\
+ \\
+\end{array}$ & $\begin{array}{l}\mathbf{N T} \\
\text { NT } \\
\text { NT } \\
\mathbf{N T} \\
\mathbf{P}_{1} \\
\mathbf{P}_{2} \\
\mathbf{P}_{1} \\
\mathbf{P}_{1} \\
\mathbf{N T}^{\prime} \\
\mathbf{N T}\end{array}$ \\
\hline $\begin{array}{c}1 \\
1 \\
1 \\
\text { NT } \\
\text { NT }\end{array}$ & $\begin{array}{c}2 \\
2 \\
2 \\
\text { NT } \\
\text { NT }\end{array}$ & $\begin{array}{l}\text { C } \\
\text { C } \\
\text { NT } \\
\text { NT }\end{array}$ & $\begin{array}{c}1-2 \\
2 \\
1-2 \\
N T \\
N T\end{array}$ & $\begin{array}{l}\text { NT } \\
\text { NT } \\
\text { NT } \\
\text { NT } \\
\text { NT }\end{array}$ & $\begin{array}{r}3,5,13,14 \\
3,5,13,14 \\
3,5,13,14 \\
\text { NT } \\
\text { NT }\end{array}$ & $\begin{array}{c}1 \\
1 \\
1 \\
\text { NT } \\
\text { NT }\end{array}$ & $\begin{array}{c}\mathbf{O} \\
\mathbf{B} \\
\mathbf{B} \\
\mathbf{N T} \\
\mathbf{A}_{1}\end{array}$ & $\begin{array}{l}\text { MSNs } \\
\text { MSN's } \\
\text { MSN's } \\
\text { NTT }^{-1} \\
\text { MSM's }\end{array}$ & $\begin{array}{l}\mathbf{R}_{1} \mathbf{R}_{2} \\
\mathbf{R}_{1} \mathbf{R}_{1} \\
\mathbf{R}_{1} \mathbf{R}_{2} \\
\mathbf{N T}_{\mathbf{T}} \\
\mathbf{R}_{\mathbf{1}} \mathbf{R}_{1}\end{array}$ & $\begin{array}{l}+ \\
+ \\
+ \\
\text { NT } \\
-\end{array}$ & $\begin{array}{l}+ \\
+ \\
+ \\
\text { NT } \\
+\end{array}$ & $\begin{array}{l}+ \\
\overline{-} \\
\text { NT } \\
+\end{array}$ & $\begin{array}{c}- \\
+ \\
+ \\
\text { NT } \\
-\end{array}$ & $\begin{array}{l}+ \\
+ \\
+ \\
\text { NT } \\
\text { NT }\end{array}$ & $\begin{array}{l}\text { NT } \\
\text { NT } \\
\text { NT } \\
\text { NT } \\
\text { NT }\end{array}$ & $\begin{array}{l}+ \\
+ \\
+ \\
\text { NT } \\
\text { NT }\end{array}$ & $\begin{array}{c}\mathbf{P}_{2} \\
\mathbf{P}_{2} \\
\mathbf{P}_{2} \\
\mathbf{N}_{\mathbf{T}} \\
\mathbf{P}_{1}\end{array}$ \\
\hline
\end{tabular}


Appendix II

SUMMARY OF FAMILY DATA

\begin{tabular}{|c|c|c|c|c|c|}
\hline $\begin{array}{l}\text { Pedigree } \\
\text { No. }\end{array}$ & Date of birth & $\begin{array}{l}\text { Date of } \\
\text { death }\end{array}$ & Parents & Comments* & Karyotype \\
\hline I.16 & 14 Jan. 1889 & Unknown & - & $\begin{array}{l}\text { Ukranian, at present suffering from } \\
\text { Parkinson's disease; low-normal } \\
\text { intelligence } \\
\text { No data }\end{array}$ & $46, X Y, \operatorname{ins}(11 ; 18)(p 15 ; q 11 q 21)$ \\
\hline $\begin{array}{l}\text { II. } 1 \\
\text { II. } \\
\text { II. } 4\end{array}$ & $\begin{array}{l}\overline{1929} \\
1931\end{array}$ & $\bar{z}$ & $\begin{array}{l}\text { I. } 16 ; 1.17 \\
\text { I. } 16 ; \mathrm{I} .17 \\
\text { I. } .16 ; \mathrm{I} .17\end{array}$ & $\begin{array}{l}\text { Stillborn female; no other data } \\
\text { Normal phenotype; no children } \\
\text { Severely retarded; see text }\end{array}$ & $\begin{array}{l}\overline{46, X Y} \\
46, X X,-18,+\operatorname{der}(18), \text { ins }(11 ; 18) \\
\text { (p15;q11q21)pat }\end{array}$ \\
\hline II.5 & 1933 & 一 & I.16; I.17 & As II.4 & $\begin{array}{l}46, X Y,-18,+\operatorname{der}(18), \operatorname{ins}(11 ; 18) \\
(\mathrm{p} 15 ; \mathrm{q} 11 \mathrm{q} 21) \text { pat }\end{array}$ \\
\hline II.6 & 1935 & 一 & I.16; I.17 & As II.4 & 46,XY, $-18,+\operatorname{der}(18), \operatorname{ins}(11 ; 18)$ \\
\hline II.7 & 1938 & - & I.16; I.17 & $\begin{array}{l}\text { Mother of two normal children; apparently } \\
\text { of low-normal intelligence; no further } \\
\text { examination permitted }\end{array}$ & $\begin{array}{l}\text { (p15;q11q21)pat } \\
\text { (p), } 11 \text {, ins }(11 ; 18)\end{array}$ \\
\hline II.9 & 1940 & - & $\mathrm{I} .16 ; \mathrm{I} .17$ & Father of the propositus; no obvious & $46, X Y$,ins $(11 ; 18)(p 15 ; q 11 q 21)$ pat \\
\hline $\begin{array}{l}\text { II.10 } \\
\text { II.11 } \\
\text { II.13 }\end{array}$ & $\begin{array}{l}1942 \\
1943 \\
1945\end{array}$ & $\bar{Z}$ & $\begin{array}{l}\mathrm{I} .16 ; \overline{\mathrm{I}} .17 \\
\mathrm{I} .16 ; \mathrm{I} .17\end{array}$ & $\begin{array}{l}\text { Mother of the propositus } \\
\text { No data } \\
\text { Dull low-normal intelligence; emotional } \\
\text { instability; otherwise normal phenotype }\end{array}$ & $\begin{array}{l}\text { 46,XX } \\
\text { No karyotype } \\
46, \mathrm{XX} \text {,ins }(11 ; 18)(\mathrm{p} 15 ; \mathrm{q} 11 \mathrm{q} 21) \text { pat }\end{array}$ \\
\hline II.15 & 1947 & - & I.16; 1.17 & Possible mild mental retardation; obtained & $46, \mathrm{XX}$,ins $(11 ; 18)(\mathrm{p} 15 ; \mathrm{q} 11 \mathrm{q} 21)$ pat \\
\hline II.17 & 1950 & 一 & I.16; I.17 & $\begin{array}{l}\text { Dull normal intelligence; obese and resembles } \\
\text { other family members including II.4; } \\
\text { deep set eyes; mild mid-face retraction }\end{array}$ & $46, X X$,ins $(11 ; 18)(\mathrm{p} 15 ; \mathrm{q} 11 \mathrm{q} 21)$ pat \\
\hline III.1 & $\begin{array}{l}1962 \\
1964\end{array}$ & - & II.7; II.8 & $\begin{array}{l}\text { These two girls are reported as normal by } \\
\text { their mother and doing well in school; no } \\
\text { studies possible }\end{array}$ & ( \\
\hline III.3 & 7 July 1969 & - & II.9; II.10 & Sister of propositus; see text & $\begin{array}{l}\text { 46,XX, - 11, + der }(11), \text { ins }(11 ; 18) \\
\quad(p 15 ; q 11 \text { q21)pat }\end{array}$ \\
\hline III.4 $\}$ & Dec. 1969 & - & II.9; II.10 & Two abortuses 10 -week gestation & - \\
\hline III.6 & 12 Nov. 1970 & - & II.9; II.10 & Propositus, see text & $46, X Y$,ins $(11 ; 18)(p 15 ; q 11 q 21)$ pato \\
\hline $\left.\begin{array}{l}\text { III. } \\
\text { III.8 }\end{array}\right\}$ & May 1971 & - & II.9; II.10 & Twin abortuses; no data & 一 \\
\hline $\begin{array}{l}\text { III.9 } \\
\text { III. } 10\end{array}$ & $\begin{array}{l}\text { Sept. } 1971 \\
21 \text { July } 1972\end{array}$ & - & $\begin{array}{l}\text { II.9; II.10 } \\
\text { II.9; II.10 }\end{array}$ & $\begin{array}{l}\text { Spontaneous abortion; no data } \\
\text { Sister of propositus; see text }\end{array}$ & 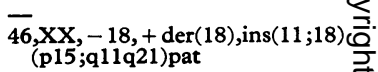 \\
\hline $\left.\begin{array}{l}\text { III.11 } \\
\text { III.12 } \\
\text { III.13 }\end{array}\right\}$ & 一 & 一 & II.11; II.12 & No data & - \\
\hline III.14 & 20 April 1966 & 一 & II.13; II.14 & $\begin{array}{l}\text { Infantile behaviour; aggressive; speech } \\
\text { disorder; learning disability and } \\
\text { emotional disturbance; IQ } 83\end{array}$ & 46.XX,ins $(11 ; 18)(\mathrm{p} 15 ; \mathrm{q} 11 \mathrm{q} 21) \mathrm{mat}$ \\
\hline $\begin{array}{l}\text { III.15 } \\
\text { III.16 }\end{array}$ & 7 Oct. 1969 & - & $\begin{array}{l}\text { II.13; II.14 } \\
\text { II.13; II.14 }\end{array}$ & $\begin{array}{l}\text { Possible early spontaneous abortion; no data } \\
\text { Mild spastic quadriplegia; slurring of } \\
\text { speech; poor vocabulary; recurrent upper } \\
\text { respiratory infections; remainder of } \\
\text { physical examination normal; IQ } 85\end{array}$ & $\begin{array}{l}\overline{46, X X},-11,+\operatorname{der}(11), \operatorname{ins}(11 ; 18) \\
(\text { p15;q11q21)mat }\end{array}$ \\
\hline III.17 & 14 Nov. 1970 & 一 & II.15; II.16 & $\begin{array}{l}\text { Mild mid-face retraction; slow but no other } \\
\text { abnormalities; able to repeat in 'parrot } \\
\text { fashion' with little understanding }\end{array}$ & $46, \mathrm{XY}$,ins $(11 ; 18)(\mathrm{p} 15 ; \mathrm{q} 11 \mathrm{q} 21) \mathrm{mat}$ \\
\hline III.18 & Dec. 1971 & 15 Jan. 1972 & II.15; II.16 & $\begin{array}{l}\text { Cause of death - aspiration pneumonia; } \\
\text { according to physician there were no } \\
\text { congenital anomalies and child was } \\
\text { generally normal; no necropsy }\end{array}$ & 一 \\
\hline $\begin{array}{l}\text { III.19 } \\
\text { III. } 20\end{array}$ & $\begin{array}{l}31 \text { Jan. } 1973 \\
14 \text { Aug. } 1971\end{array}$ & 二 & $\begin{array}{l}\text { II.15; II.16 } \\
\text { II.17; II.18 }\end{array}$ & $\begin{array}{l}\text { Clinically normal female infant } \\
\text { Early miscarriage; poor maternal recall; no } \\
\text { further data obtainable }\end{array}$ & $\underline{46, X X}$ \\
\hline
\end{tabular}

* In generation II, there were several early abortions about which there are no data. 